\title{
Efficacy of Selected Insecticides as Replacement for Neonicotinoids in Managing Sweetpotato Whitefly on Poinsettia
}

\author{
Gunbharpur Singh Gill ${ }^{1}$ and Juang Horng Chong ${ }^{1}$
}

AdDITIONAl INDEX wORDs. Bemisia tabaci, Euphorbia pulcherrima, floriculture, foliar spray, substrate drench

SUMMARY. Management of sweetpotato whitefly (Bemisia tabaci), one of the most economically important pests of poinsettia (Euphorbia pulcherrima), relies heavily on neonicotinoid insecticides. Growers are seeking insecticide alternatives to neonicotinoids due to market demands. Although several systemic and translaminar insecticides have been suggested as alternatives to neonicotinoids, no published study has simultaneously compared their efficacies against sweetpotato whiteflies. This study compared the efficacies of 10 systemic and translaminar alternative insecticides with those of two systemic neonicotinoids, when all products were applied as foliar spray (twice at $14 \mathrm{~d}$ ) or substrate drench (once) against sweetpotato whiteflies on poinsettia plants. Sweetpotato whitefly nymph and adult densities were examined 2 weeks before the first application (pretreatment), and weekly after the application for 8 weeks. Results showed that insecticides varied greatly in their efficacy, particularly against adults, and that spray application provided more effective suppression of nymphs than drench application. Spray and drench applications of imidacloprid and dinotefuran were consistently the most effective against sweetpotato whitefly nymphs and adults. Among the neonicotinoid alternatives, cyantraniliprole was the most effective insecticide in reducing sweetpotato whitefly nymph densities by both spray and drench application methods, with efficacy comparable to those of imidacloprid and dinotefuran. Although less effective than cyantraniliprole, foliar sprays of afidopyropen, chloratraniliprole, cyclaniliprole, flonicamid, flupyradifurone, pyrifluquinazon, spirotetramat, and sulfoxaflor + spinetoram were also effective against nymphs and could serve as partners in an insecticide rotation program.

$\mathrm{P}$ oinsettia (Euphorbia pulcherri$m a)$ is a major floricultural crop in North America. In 2019, 1193 operations produced close to 47 million

Received for publication 5 Apr. 2021. Accepted for publication 17 Aug. 2021.

Published online 13 October 2021.

${ }^{1}$ Clemson University, Pee Dee Research and Education Center, 2200 Pocket Road, Florence, SC 29506

Shawn Chandler, Shay Cook, Mary Gaskins, and Courtney Gregg of Clemson University provided technical assistance in maintaining experimental plants and collecting data in this experiment. BASF Corp., Bayer CropScience, Corteva Agriscience, FMC Corp., OHP, Inc., SePRO Corp., Syngenta Crop Protection, and Valent USA provided the insecticides evaluated in this experiment. This report is based on work supported by U.S. Department of Agriculture, National Institute of Food and Agriculture, under project number SC-1700534, and is Technical Contribution no. 6964 of the Clemson University Experiment Station. Mention of trade names or commercial products in this report is solely for the purpose of providing scientific information and does not imply recommendation or endorsement by Clemson University.

Current address for G.S.G.: Iron Ox, Inc., 955 Terminal Way, San Carlos, CA 94070

J.H.C. is the corresponding author. E-mail: juanghc@clemson.edu.

This is an open access article distributed under the CC BY-NC-ND license (https://creativecommons. org/licenses/by-nc-nd/4.0/).

https://doi.org/10.21273/HORTTECH04853-21 pots that valued nearly $\$ 216$ million in the United States (U.S. Department of Agriculture, National Agricultural Statistics Service, 2019). Whiteflies (Aleyrodidae), particularly sweetpotato whitefly (Bemisia tabaci), are the most economically important arthropod pests of poinsettia (Martin and Mound, 2007; Perring et al., 2018). Their presence is objectionable to consumers, and the removal of a large amount of sap and nutrients by a large population can also retard the growth of poinsettia (Wang et al., 2017). Sweetpotato whiteflies also produce honeydew, which is an excellent substrate for the growth of black sooty mold (Byrne and Bellows, 1991). The presence of shiny, sticky honeydew and black sooty mold further reduces the marketability and value of a poinsettia crop.

Although a treatment threshold or tolerable sweetpotato whitefly density on poinsettia is poorly defined at retail outlets (Vafaie et al., 2020), most poinsettia growers operate under the assumption of "zero tolerance" for sweetpotato whitefly. Biological control programs using entomopathogenic fungi and parasitoids at various stages of a crop cycle were very successful in some studies (Buitenhuis et al., 2016; Krauter et al., 2017; Stevens et al., 2000; Van Driesche et al., 1999); however, sweetpotato whitefly management programs in poinsettia crops at many operations continue to rely on highly intensive insecticide application programs (Hoddle and Van Driesche, 1996; Stevens et al., 2000; Vafaie et al., 2021).

Drench and/or foliar applications of neonicotinoids and other systemic or translaminar insecticides form the basis of conventional chemical management programs against sweetpotato whitefly on poinsettia (Stevens et al., 2000; Vafaie et al., 2021). Translaminar pesticides, sometimes called locally systemic pesticides, are those that move into and across a leaf but remain restricted to the leaf that has received the treatment (McGrath, 2004). Systemic pesticides, in addition to having translaminar activity, can be translocated throughout the plants via the xylem or phloem. Reliance on neonicotinoid insecticides for pest management has certain benefits

\begin{tabular}{llll}
\hline $\begin{array}{l}\text { Units } \\
\text { To convert U.S. to SI, } \\
\text { multiply by }\end{array}$ & U.S. unit & SI unit & $\begin{array}{l}\text { To convert SI to U.S., } \\
\text { multiply by }\end{array}$ \\
\hline 29.5735 & $\mathrm{fl} \mathrm{oz}$ & $\mathrm{mL}$ & 0.0338 \\
0.0781 & $\mathrm{fl} \mathrm{oz} / 100 \mathrm{gal}$ & $\mathrm{mL} \cdot \mathrm{L}^{-1}$ & 12.8000 \\
0.3048 & $\mathrm{ft}$ & $\mathrm{m}$ & 3.2808 \\
0.0929 & $\mathrm{ft}^{2}$ & $\mathrm{~m}^{2}$ & 10.7639 \\
3.7854 & $\mathrm{gal}$ & $\mathrm{L}$ & 0.2642 \\
2.54 & inch $(\mathrm{es})$ & $\mathrm{cm}$ & 0.3937 \\
25.4 & inch(es) & $\mathrm{mm}$ & 0.0394 \\
6.4516 & inch & $\mathrm{cm}$ & 0.1550 \\
28.3495 & $\mathrm{oz}$ & $\mathrm{g}$ & 0.0353 \\
0.0749 & $\mathrm{Oz} / 100 \mathrm{gal}$ & $\mathrm{g} \cdot \mathrm{L}^{-1}$ & 13.3526 \\
1 & $\mathrm{ppm}$ & $\mathrm{mg} \cdot \mathrm{L}^{-1}$ & 1 \\
6.8948 & $\mathrm{psi}$ & $\mathrm{kPa}$ & 0.1450 \\
$\left({ }^{\circ} \mathrm{F}-32\right) \div 1.8$ & ${ }^{\circ} \mathrm{F}$ & ${ }^{\circ} \mathrm{C}$ & $\left({ }^{\circ} \mathrm{C} \times 1.8\right)+32$ \\
& & & \\
\end{tabular}

Hortlechnology $\cdot$ December $202131(6)$ 
and risks (Bethke and Cloyd, 2009). Neonicotinoids provide a major benefit of effective and persistent suppression of sweetpotato whitefly populations. However, the negative impacts of neonicotinoids on pollinator health have been prominently noted (Goulson et al., 2015). Despite their generally poor understanding of the risks and benefits of neonicotinoids to pollinators and floriculture, many consumers demand pollinator-friendly, pollinatorsafe, or neonicotinoid-free plants (Blacquière et al., 2012; Getter et al., 2016; Rihn and Khachatryan, 2016; Wei et al., 2020; Wollaeger et al., 2015). In response to changing consumer preference, many operations have eliminated or planned to eliminate neonicotinoids from their pest management programs. Growers interested in producing neonicotinoid-free poinsettias (and other ornamental plants) are looking for alternatives to neonicotinoids.

We conducted a study to document the efficacies of selected systemic and translaminar insecticides, which have been identified or are being used as alternatives to neonicotinoids by growers, in managing a sweetpotato whitefly population when the insecticides were applied as foliar sprays or substrate drench to a poinsettia crop. The efficacies of these alternatives were compared with dinotefuran and imidacloprid, two neonicotinoids commonly used for sweetpotato whitefly management in poinsettia production. The selected alternatives represent six modes of action, with chemical and practical application properties that are different from the neonicotinoids (Chong et al., 2015). Although reports of the efficacy and comparisons among small groups of the selected alternatives are available (e.g., Arthurs et al., 2017), there is no published study in which all of these alternatives are compared simultaneously. The efficacy of the selected alternatives relative to commonly used neonicotinoids could be interpreted more accurately in a simultaneous comparative study. Our study goal was to provide growers and pest management practitioners the information needed to select the most efficacious alternative(s) to neonicotinoids.

\section{Materials and methods}

Plant maintenance and SWEetPOTATO WHITEFLY INFESTATION. Rooted 'Enduring Red' poinsettia cuttings, which were available from the propagator (Raker-Roberta's Young Plants, Litchfield, MI) at the time of the experiment, were planted in standard 6-inch plastic pots $[\approx 1 \mathrm{~L}$ (Landmark Plastic Corp., Akron, OH)] filled with moist substrate (Fafard 3M; Sun Gro Horticulture, Agawam, MA). The propagator reported that the stock plants were treated with azadirachtin and Beauveria bassiana (trade name, application rate, and application frequency of the insecticides were not reported) before the cuttings were taken. Residue of these insecticides broke down quickly; thus, we believe they did not influence the outcomes of our intended treatments 8 weeks after transplant.

Each pot was fertilized at transplant with 1 teaspoon $(\approx 10 \mathrm{~g}) 14 \mathrm{~N}-$ 6.1P-11.6K slow-release fertilizer (Osmocote 14-14-14; ICL Specialty Fertilizers, Summerville, SC). Plants were grown in a greenhouse $(8 \times 8 \mathrm{~m})$ maintained at $28 \pm 5{ }^{\circ} \mathrm{C}$ and $75 \% \pm$ $15 \%$ relative humidity at the research greenhouse complex at Clemson University Pee Dee Research and Education Center, Florence, SC. The plants were irrigated daily and fertilized at 150 ppm nitrogen weekly. No insecticide or fungicide, other than those evaluated, was applied between transplant and the end of this study.

The experiment began 8 weeks after transplant when the plants reached 6 to 8 inches. The plants were infested naturally during the 8 -week period by sweetpotato whitefly adults (MEAMl or "B" biotype) dispersing from a colony maintained on collards (Brassica oleracea Acephala group) in another greenhouse unit of the same greenhouse complex. Plants were assigned to the treatments based on pretreatment sweetpotato whitefly nymph densities to achieve similar densities among treatments.

INSECTICIDE APPLICATIONS. We compared the efficacy of 10 systemic or translaminar insecticides with those of two neonicotinoid insecticides registered for sweetpotato whitefly management on ornamental crops (Table 1). Imidacloprid (Marathon II; OHP, Bluffton, SC) and dinotefuran (Safari 20SG; Valent USA, Walnut Creek, CA) are neonicotinoids [Insecticide Resistance Action Committee (IRAC) Group 4A], flupyradifurone (Altus; Bayer Environmental Science, Cary,
NC) is a butenolide (IRAC Group 4D), spirotetramat (Kontos, Bayer Environmental Science) is a tetramic acid derivative (IRAC Group 23), and chlorantraniliprole (Acelepryn; Syngenta Crop Protection, Greensboro, NC) and cyantraniliprole (Mainspring GNL, Syngenta Crop Protection) are diamides (IRAC Group 28); these insecticides are systemic and are registered for both spray and drench applications. Cyclaniliprole (Sarisa, OHP) is another diamide, but is registered only for foliar application. XXpire (Corteva AgriSciences, Johnston, IA) contains two active ingredients (sulfoxaflor and spinetoram); sulfoxaflor (IRAC Group 4C) is a systemic insecticide but XXpire is registered for foliar application only. Afidopyropen (Ventigra; BASF Corp., Research Triangle Park, NC), pymetrozine (Endeavor, Syngenta Crop Protection), pyrifluquinazon (Rycar; SePRO Corp., Carmel, IN) and flonicamid (Aria; FMC Corp., Philadelphia, PA) target different sites on the chordotonal organs; only pymetrozine is registered for both foliar and drench applications. To achieve complete $2 \times 12$ factorial design, all selected insecticides were applied as foliar sprays (twice at 14-d interval) or substrate drench (once) at their respective label rates (Table 1 ). It is important to recognize that afidopyropen, cyclaniliprole, flonicamid, pyrifluquinazon, and spinetoran + sulfoxaflor are not registered for drench application in greenhouses in the United States.

A nonionic surfactant (Capsil; Aquatrols, Paulsboro, NJ) was mixed with all insecticide solutions used for foliar spray at the label rate of $6 \mathrm{fl} \mathrm{oz} /$ $100 \mathrm{gal}$, and surfactant-alone solution was used as the untreated control for foliar spray. Surfactant was not mixed in solutions used for substrate drench; instead, water was used as the untreated control for drench treatment.

Foliar applications were made on 10 and 24 Sept. 2019. Plants assigned to a treatment were arranged randomly within a premarked $5 \times 5$ - $\mathrm{ft}\left(25 \mathrm{ft}^{2}\right)$ area on the greenhouse floor, and the premeasured insecticide solution was applied to the plants at an application volume of $100 \mathrm{gal} / \mathrm{acre}$ with a compressed carbon dioxide sprayer (30 psi) fitted with a single flat fan nozzle (XR8002VS; TeeJet Technologies, Springfield, IL). Drench application was applied on 10 Sept. 2019. Insecticide solutions were prepared and poured 
Table 1. List of insecticides, and their application methods and rates evaluated against sweetpotato whiteflies on poinsettia plants grown in greenhouse.

\begin{tabular}{|c|c|c|c|}
\hline Treatment $^{\mathrm{z}}$ & $\begin{array}{l}\text { Product trade } \\
\text { name }^{\mathrm{y}}\end{array}$ & $\begin{array}{l}\text { Application } \\
\text { method }^{\mathrm{x}}\end{array}$ & $\begin{array}{c}\text { Product application } \\
\text { rate }^{w}\end{array}$ \\
\hline \multirow[t]{2}{*}{ Afidopyropen } & \multirow[t]{2}{*}{ Ventigra } & Spray & $7 \mathrm{fl} \mathrm{oz} / 100 \mathrm{gal}$ \\
\hline & & Drench & $7 \mathrm{fl} \mathrm{oz} / 100 \mathrm{gal}$ \\
\hline \multirow[t]{2}{*}{ Chlorantraniliprole } & \multirow[t]{2}{*}{ Acelepryn } & Spray & $8 \mathrm{fl} \mathrm{oz} / 100 \mathrm{gal}$ \\
\hline & & Drench & $12 \mathrm{fl} \mathrm{oz} / 100 \mathrm{gal}$ \\
\hline \multirow[t]{2}{*}{ Cyantraniliprole } & \multirow[t]{2}{*}{ Mainspring GNL } & Spray & $8 \mathrm{fl} \mathrm{oz} / 100 \mathrm{gal}$ \\
\hline & & Drench & $12 \mathrm{fl} \mathrm{oz} / 100 \mathrm{gal}$ \\
\hline \multirow[t]{2}{*}{ Cyclaniliprole } & \multirow[t]{2}{*}{ Sarisa } & Spray & $27 \mathrm{fl} \mathrm{oz} / 100 \mathrm{gal}$ \\
\hline & & Drench & $27 \mathrm{fl} \mathrm{oz} / 100 \mathrm{gal}$ \\
\hline \multirow[t]{2}{*}{ Dinotefuran } & \multirow[t]{2}{*}{ Safari $20 \mathrm{SG}$} & Spray & $8 \mathrm{oz} / 100 \mathrm{gal}$ \\
\hline & & Drench & $12 \mathrm{oz} / 100 \mathrm{gal}$ \\
\hline \multirow[t]{2}{*}{ Flonicamid } & \multirow[t]{2}{*}{ Aria } & Spray & $4.3 \mathrm{oz} / 100 \mathrm{gal}$ \\
\hline & & Drench & $4.3 \mathrm{oz} / 100 \mathrm{gal}$ \\
\hline \multirow[t]{2}{*}{ Flupyradifurone } & \multirow[t]{2}{*}{ Altus } & Spray & $14 \mathrm{fl} \mathrm{oz} / 100 \mathrm{gal}$ \\
\hline & & Drench & $3.7 \mathrm{fl} \mathrm{oz} / 100 \mathrm{gal}$ \\
\hline \multirow[t]{2}{*}{ Imidacloprid } & \multirow[t]{2}{*}{ Marathon II } & Spray & $1.7 \mathrm{fl} \mathrm{oz} / 100 \mathrm{gal}$ \\
\hline & & Drench & $\begin{array}{l}1.7 \mathrm{fl} \mathrm{oz} \text { per } 1000 \\
6 \text {-inch pots }\end{array}$ \\
\hline Nonionic surfactant & Capsil & Spray & $6 \mathrm{fl} \mathrm{oz} / 100 \mathrm{gal}$ \\
\hline \multirow[t]{2}{*}{ Pymetrozine } & \multirow[t]{2}{*}{ Endeavor } & Spray & $5 \mathrm{oz} / 100 \mathrm{gal}$ \\
\hline & & Drench & $5 \mathrm{oz} / 100 \mathrm{gal}$ \\
\hline \multirow[t]{2}{*}{ Pyrifluquinazon } & \multirow[t]{2}{*}{ Rycar } & Spray & $3.2 \mathrm{fl} \mathrm{oz} / 100 \mathrm{gal}$ \\
\hline & & Drench & $3.2 \mathrm{fl} \mathrm{oz} / 100 \mathrm{gal}$ \\
\hline \multirow[t]{2}{*}{ Spinetoram + sulfoxaflor } & \multirow[t]{2}{*}{ XXpire } & Spray & $2.75 \mathrm{oz} / 100 \mathrm{gal}$ \\
\hline & & Drench & $2.75 \mathrm{oz} / 100 \mathrm{gal}$ \\
\hline \multirow[t]{2}{*}{ Spirotetramat } & \multirow[t]{2}{*}{ Kontos } & Spray & $3.4 \mathrm{fl} \mathrm{oz} / 100 \mathrm{gal}$ \\
\hline & & Drench & $\begin{array}{l}3.4 \mathrm{fl} \mathrm{oz} / 1000 \\
6 \text {-inch pots }\end{array}$ \\
\hline Water & - & Drench & $\mathrm{N} / \mathrm{A}$ \\
\hline
\end{tabular}

${ }^{\mathrm{z}}$ Nonionic surfactant (polyether-polymethylsiloxane-copolymer) was added to all insecticide solutions for foliar spray application. Surfactant-alone solution was used as the untreated control for foliar spray application, whereas water was used as untreated control for substrate drench application.

yAcelepryn (18.4\% chlorantraniliprole; Syngenta Crop Protection, Greensboro, NC), Altus (17.09\% flupyradifurone; Bayer Environmental Science, Cary NC), Aria (50\% flonicamid; FMC Corp., Philadelphia, PA), Capsil (100\% polyether-polymethylsiloxane-copolymer; Aquatrols, Paulsboro, NJ), Endeavor (50\% pymetrozine, Syngenta Crop Protection), Kontos $(22.4 \%$ spirotetramat, Baver Environmental Science), Mainspring GNL (18.66\% cyantraniliprole, Syngenta Crop Protection), Marathon II (21.4\% imidacloprid; OHP, Bluffton, SC), Rycar (20.2\% pyrifluquinazon; SePRO Corp., Carmel, IN), Safari 20 SG (20\% dinotefuran; Valent USA, Walnut Creek, CA), Sarisa (4.55\% cyclaniliprole, OHP), Ventigra (9.78\% afidopyropen; BASF Corp., Research Triangle Park, NC), and XXpire (20\% spinetoram $+20 \%$ sulfoxaflor; Corteva Agriscience, Johnston, IA).

${ }^{\mathrm{x}}$ Foliar sprays were applied twice in $14 \mathrm{~d}$, whereas substrate drench was applied once. Afidopyropen, cyclaniliprole, flonicamid, pyrifluquinazon, and spinetoran + sulfoxaflor are not registered for drench application in greenhouses in the United States.

${ }^{\mathrm{w}} 1 \mathrm{fl} \mathrm{oz} / 100 \mathrm{gal}=0.0781 \mathrm{~mL} \cdot \mathrm{L}^{-1}, 1 \mathrm{oz} / 100 \mathrm{gal}=0.0749 \mathrm{~g} \cdot \mathrm{L}^{-1}, 1 \mathrm{fl} \mathrm{oz}=29.5735 \mathrm{~mL}, 1$ inch $=2.54 \mathrm{~cm}$.

evenly over substrate surface at an application volume of $4 \mathrm{fl} \mathrm{oz} / \mathrm{pot}$ ( $\mathrm{rec}-$ ommended application volume for 6inch pots) with a glass beaker. The plants were irrigated $4 \mathrm{~h}$ before the treatment, but we did not measure the substrate moisture content before drench treatment.

Plants were returned to the benches when the insecticide solutions on foliage had dried or stopped leaching from the pots. Sprayed and drenched plants were arranged in the same block, with treatments randomized within each block. Plants were situ so that adults were not disturbed by leaf collection and flew away. The selected leaves were then detached from the plants, brought back into the laboratory in petri dishes, and the number of nymphs (all instars combined) on a randomly selected 1 -inch ${ }^{2}$ area on each leaf was counted under stereomicroscopes.

We did not observe any phytotoxicity (leaf area showing chlorosis or necrosis) and residue (leaf area covered with residue) on poinsettia leaves at 7 and $14 \mathrm{~d}$ after each application of any insecticide.

Data analysis. Densities of adults and nymphs on the three leaves of a single plant were averaged for each sampling date, and the average densities were $\log _{10}(\mathrm{x}+0.1)$-transformed before been subjected to twoway analysis of variance (ANOVA), with product and application method as the main factors [PROC GLM (SAS version 9.2; SAS Institute, Cary, $\mathrm{NC})$ ]. When ANOVA detected significant difference at $\alpha=0.05$, backtransformed means were separated with Fisher's least significant difference test. Densities of whitefly adults and nymphs on water- or surfactanttreated plants were used to calculate percent reduction in whitefly population for drench and spray treatments, respectively.

\section{Results}

INSECTICIDAL EFFICACY AGAINST SWEETPOTATO WHITEFLY NYMPHS. Pretreatment nymph and adult densities did not differ significantly among insecticides and application methods (Tables 2 and 3 ), suggesting that assigning plants to treatments based on pretreatment nymph densities successfully created similar initial sweetpotato whitefly densities among treatments. Mean densities of nymphs on treated plants were not significantly lower than those on the water- or surfactanttreated plants (control) at 7 and $14 \mathrm{~d}$ after treatment (DAT) (Table 2).

Mean nymph densities were significantly different among insecticides at 28 to 56 DAT and between application methods at 28 to 42 DAT (Table 2). At 28 DAT, plants sprayed with spirotetramat, cyantraniliprole, and cyclaniliprole harbored $90 \%, 84 \%$, and $82 \%$, respectively, fewer nymphs than plants sprayed with surfactant solution. At 35 DAT, all insecticide- 


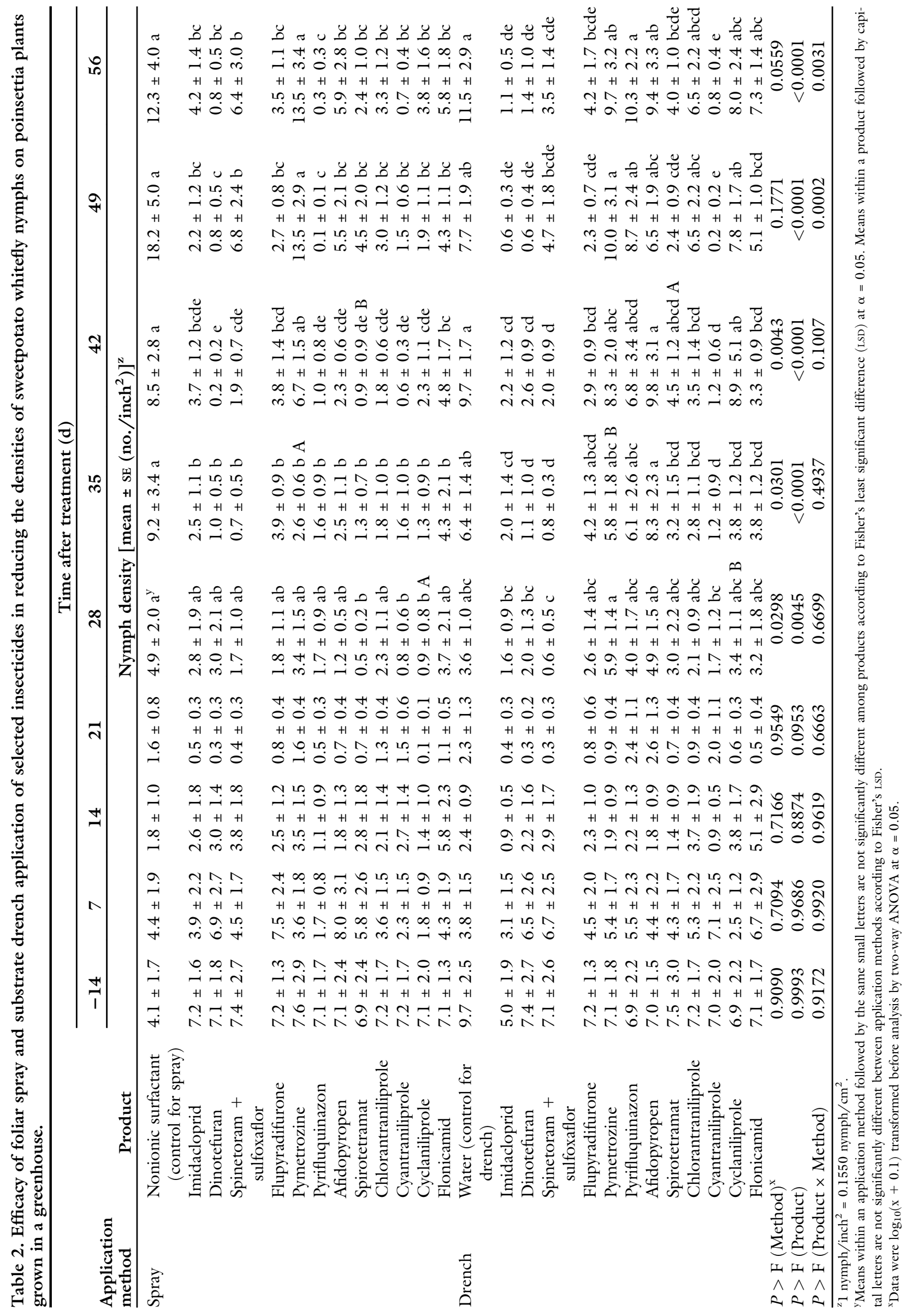




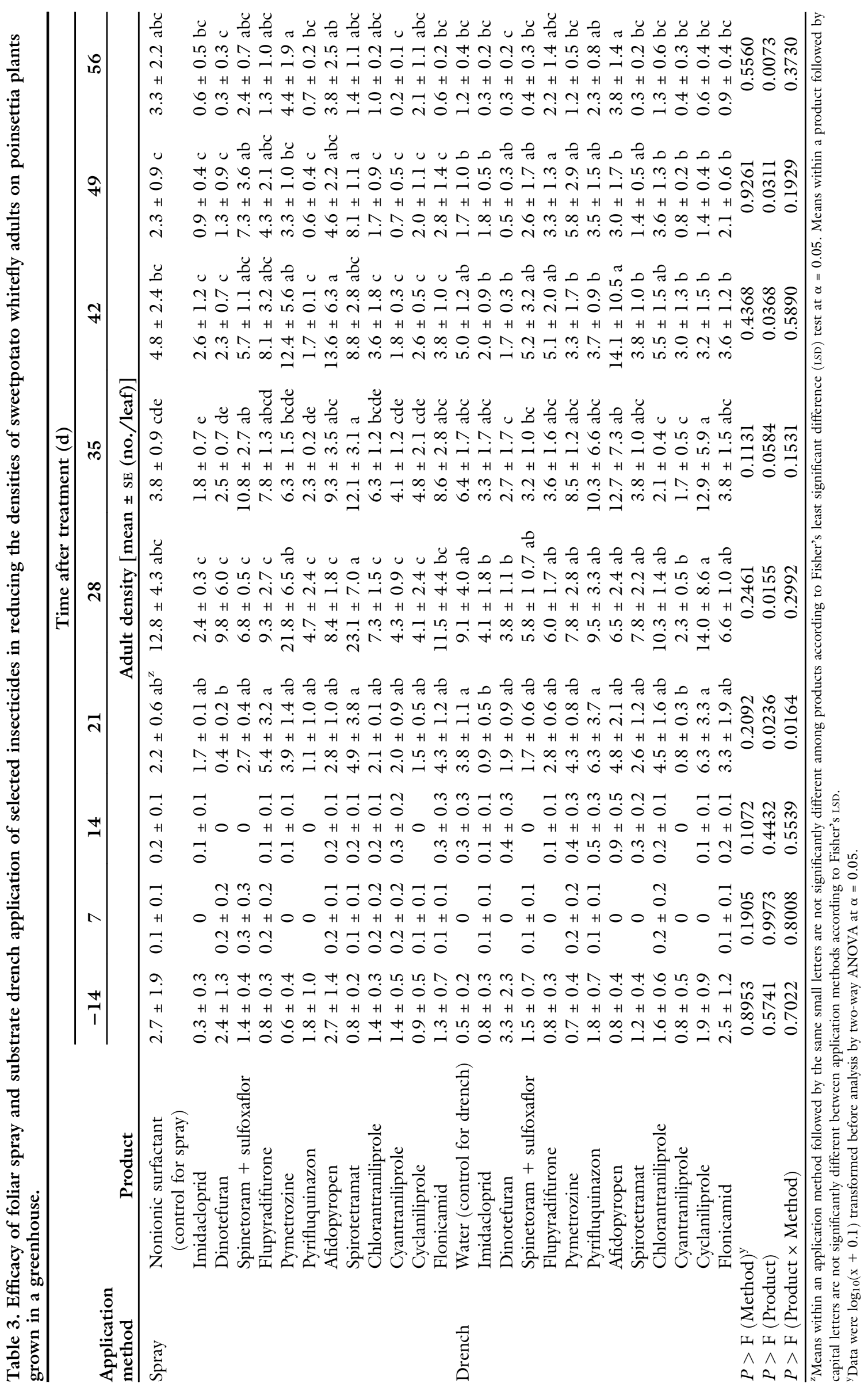


sprayed plants and plants drenched with imidacloprid, dinotefuran, spinetoram + sulfoxaflor, and cyantraniliprole had significantly lower densities of nymphs than their respective untreated control. At 42 to 56 DAT, plants sprayed with all insecticides, except for pymetrozine, harbored significantly lower densities of nymphs. Plants drenched with imidacloprid, dinotefuran, flupyradifurone, and cyantraniliprole had significantly fewer nymphs than the water-treated plants at 42 to 56 DAT (Table 2). Plants drenched with spinetoram + sulfoxaflor, spirotetramat, chlorantraniliprole, and flonicamid, on the other hand, produced inconsistent results and had significantly fewer nymph densities compared with water-treated plants at either one or two of three intervals [i.e., 42, 49, and 56 DAT (Table 2)]. Plants sprayed with dinotefuran, pyrifluquinazon, and cyantraniliprole, and those drenched with imidacloprid, dinotefuran, and cyantraniliprole consistently had the lowest nymph densities at 35 to 56 DAT.

We observed a general pattern for plants sprayed with an insecticide to harbor fewer nymphs than plants drenched with the same insecticides (Table 2). However, we did not observe significantly different nymph densities on plants treated with different application methods of the same insecticides at 28 to 56 DAT, except for cyclaniliprole at 28 DAT, pymetrozine at $35 \mathrm{DAT}$, and spirotetramat at 42 DAT (Table 2). Spray application of cyclaniliprole at $28 \mathrm{DAT}$, pymetrozine at $35 \mathrm{DAT}$, and spirotetramat at 42 DAT was significantly more effective in reducing nymph densities than drench application.

ANOVA detected a significant interaction between insecticides and application methods at 49 and 56 DAT (Table 2). The interaction appeared to be driven, at least in part, by a greater reduction in nymph densities by spray application than by drench application of pyrifluquinazon at 49 DAT $(90 \%)$ and 56 DAT (97\%).

INSECTICIDAL EFFICACY AGAINST SWEETPOTATO WHITEFLY ADULTS. Sweetpotato whitefly adult densities fluctuated greatly among treatments in this study. Adult densities differed among insecticides at 21 to $56 \mathrm{DAT}$, but were similar between the application methods throughout this study (Table 3 ).
At 21 DAT, plants drenched with imidacloprid and cyantraniliprole had significantly lower adult densities than those drenched with water. However, for other sampling dates, insecticides and application methods that had resulted in the lowest adult densities did not result in adult densities that were significantly different from the untreated control.

A significant interaction between insecticides and application methods was detected at 21 DAT (Table 3 ). The significant interaction was partially driven by a greater reduction in adult densities due to spray application of pyrifluquinazon and cyclaniliprole compared with when the same insecticides were applied by drench.

\section{Discussion}

Efficacies of the tested insecticides against nymphs were consistent over the course of this study, whereas their efficacies against adults varied greatly among sampling intervals. The observed differences in efficacies against nymphs and adults may result from an inherent difference in susceptibility between nymphs and adults (Chen et al., 2018). For instance, spiromesifen, flonicamid, acetamiprid, thiamethoxam, and spirotetramat were more toxic to sweetpotato whitefly nymphs than adults (Brück et al., 2009; Chen et al., 2018; Kontsedalov et al., 2009). Also, untreated and treated plants were not caged, thus allowing adult sweetpotato whiteflies to disperse freely among plants in our study. Because adults typically have a greater tolerance for insecticide residue, individuals dispersing from an untreated plant to a treated plant might not be killed immediately by the insecticide residue, and thus, might have been counted during a snapshot sampling of adult abundance. Even if the residue eventually killed the adults, the data taken before they died had inflated the adult abundance on the treated plants and led us to a wrong conclusion about the toxicity of the insecticide treatment. Therefore, we question the value of a snapshot sampling approach for a highly mobile adult stage, such as that of sweetpotato whitefly, and caution against using adult counts as the sole indication of treatment effect. Our caution should be further evaluated. Our subsequent discussion in this report will focus mainly on insecticide efficacy against nymphs, which was found to generate a more consistent pattern.

We found that foliar spray application of all insecticides provided better control of sweetpotato whitefly nymphs than drench application. In our study, neonicotinoid insecticides (dinotefuran and imidacloprid) remained the most effective insecticides in suppressing nymph densities in a poinsettia crop regardless of whether the insecticides were applied as a drench or foliar spray. Among the alternatives to neonicotinoids, cyantraniliprole was the only insecticide that was consistently as effective as the neonicotinoids when applied with both application methods. However, the value of other insecticides as alternatives to neonicotinoids depended on the application method.

Foliar spray appeared to be the quicker and more effective application method compared with substrate drench in reducing the abundance of sweetpotato whitefly nymphs. Eleven of the 12 insecticides tested, when sprayed, consistently resulted in significantly lower nymph densities compared with the untreated plants from 35 to 56 DAT. Foliar sprays of cyantraniliprole, spirotetramat, and cyclaniliprole reduced nymph densities within the shortest time (28 DAT). Among these insecticides, cyantraniliprole provided the greatest suppression of nymph densities throughout the study. Our results are in line with Gill et al., (2019), where a cyantraniliprole spray application ( $8 \mathrm{fl} \mathrm{oz} / 100 \mathrm{gal}$ ) harbored significantly lower sweetpotato whitefly nymphs on poinsettia compared with flonicamid, spirotetramat, flupyradifurone, afidopyropen, pymetrozine, and dinotefuran. Similarly, a previous study on zinnia (Zinnia elegans) reported that a single spray application $(4 \mathrm{fl} \mathrm{oz} /$ $100 \mathrm{gal})$ of cyantraniliprole resulted in the lowest sweetpotato whitefly nymphal densities compared with cyclaniliprole and flonicamid insecticides (Arthurs et al., 2017). We also observed that spray applications of pyrifluquizanon and dinotefuran were as effective as cyantraniliprole in controlling sweetpotato whitefly nymphs, but the reduction in nymph densities by pyrifluquinazon and dinotefuran only became evident at 35 DAT. Spray application of imidacloprid, spinetoram + sulfoxaflor, flupyradifurone, afidopyropen, chlorantraniliprole, and flonicamid also resulted in significantly lower 
nymph densities than those on the surfactant-sprayed plants at $35 \mathrm{DAT}$, although these insecticides were not as effective as cyantraniliprole, pyrifluquinazon, and dinotefuran.

When plants were drenched with insecticides, significant reductions of nymph densities were observed on plants treated with cyantraniliprole, imidacloprid, dinotefuran, and spinetoram + sulfoxaflor at 35 DAT. However, cyantraniliprole was the only alternative that had provided consistent suppression of nymph populations most comparable to those achieved by neonicotinoids throughout this study. Drench application of flupyradifurone and spirotetramat also suppressed populations of sweetpotato whitefly nymphs; however, suppression by these insecticides was not observed until 42 and 49 DAT, respectively. Although plants drenched with spinetoram + sulfoxaflor, flonicamid, and chlorantraniliprole harbored significantly lower sweetpotato whitefly nymphal densities, their effect was not consistent throughout the study. Pymetrozine, pyrifluquinazon, afidopyropen, and cyclaniliprole were the least effective insecticides, with plants drenched with these insecticides harboring as many nymphs as the control plants (drenched with water). It is important to remember that, except for pymetrozine, these insecticides were not registered for drench application, and our data demonstrated that they should not be used as such.

The choice of an appropriate neonicotinoid alternative for the control of sweetpotato whiteflies depends on the preferred application method. Based on our study, cyantraniliprole was the most effective alternative to neonicotinoids by both spray and drench application. This insecticide reduced sweetpotato whitefly nymph densities significantly as soon as 28 DAT by foliar spray and 35 DAT by drench, and its efficacy lasted consistently throughout our study (56 DAT). Other insecticides, namely afidopyropen, chloratraniliprole, cyclaniliprole, flonicamid, flupyradifurone, pyrifluquinazon, spirotetramat, and spinetoram + sulfoxaflor are valuable partners in an insecticide rotation program when applied as foliar sprays. Some of these insecticides can also serve important roles in developing a spray program that is compatible with biological control programs against sweetpotato whiteflies and other major arthropod pests.

\section{Literature cited}

Arthurs, S., P.C. Krauter, and K.M. Heinz. 2017. Evaluation of foliar insecticides for the control of sweetpotato whitefly in zinnia. Arthropod Manage. Tests 42(1):133, https://doi.org/10.1093/amt/tsx133.

Bethke, J.A. and R.A. Cloyd. 2009. Pesticide use in ornamental production: What are the benefits? Pest Manag. Sci. 65(4):345-350, https://doi.org/10.1002/ps.1695.

Blacquière, T., G. Smagghe, C.A.M. van Gestel, and V. Mommaerts. 2012. Neonicotinoids in bees: A review on concentrations, side-effects and risk assessment. Ecotoxicology 21(4):973-992, https:// doi.org/10.1007/s10646-012-0863-x.

Brück, E., A. Elbert, R. Fischer, S. Krueger, J. Kühnhold, A.M. Klueken, R. Nauen, J.-F. Niebes, U. Reckmann, H.-J. Schnorbach, R. Steffens, and X. van Waetermeulen. 2009. Movento®, an innovative ambimobile insecticide for sucking insect pest control in agriculture: Biological profile and field performance. Crop Prot. 28(10):838-844, https://doi.org/ 10.1016/j.cropro.2009.06.015.

Buitenhuis, R., M. Brownbridge, A. Brommit, T. Saito, and G. Murphy. 2016. How to start with a clean crop: Biopesticide dips reduce populations of Bemisia tabaci (Hemiptera: Aleyrodidae) on greenhouse poinsettia propagative cuttings. Insects 7(4):48, https://doi.org/10.3390/insects 7040048 .

Byrne, D.N. and T.S. Bellows. 1991. Whitefly biology. Annu. Rev. Entomol. 36(1):431457, https://doi.org/10.1146/annurev.en. 36.010191.002243.

Chen, J.-C., Z.-H. Wang, L.-J. Cao, Y.-J. Gong, A.A. Hoffmann, and S.-J. Wei. 2018. Toxicity of seven insecticides to different developmental stages of the whitefly Bemisia tabaci MED (Hemiptera: Aleyrodidae) in multiple field populations of China. Ecotoxicology 27(6):742-751, https:// doi.org/10.1007/s10646-018-1956-y.

Chong, J.-H., W.E. Klingeman, and F. Hale. 2015. The insecticide and miticide mode of action field guide. Univ. Tennessee Coop. Ext. Serv. Bull. W415. 28 July 2021. <https://extension.tennessee.edu/ publications/Documents/W415.pdf $>$.

Getter, K.L., B.K. Behe, and H. Wollaeger. 2016. Comparative consumer perspectives on eco-friendly and insect management practices on floriculture crops. HortTechnology 26(1):46-53, https://doi.org/ 10.21273/HORTTECH.26.1.46.
Gill, S., B. Kunkel, S. Klick, R. Ross, and C. Hardcastle. 2019. Whiteflies: A major problem that just doesn't go away. GrowerTalks 83:90-94. 28 July 2021. <https://www.growertalks.com/Article/ ? articleid $=24227>$.

Goulson, D., E. Nicholls, C. Botías, and E.L. Rotheray. 2015. Bee declines driven by combined stress from parasites, pesticides, and lack of flowers. Science 347(6229):1255957, https://doi.org/ 10.1126 /science.1255957.

Hoddle, M.S. and R. Van Driesche. 1996. Evaluation of Encarsia formosa (Hymenoptera: Aphelinidae) to control Bemisia argentifolii (Homoptera: Aleyrodidae) on poinsettia (Euphorbia pulcherrima): A lifetable analysis. Fla. Entomol. 79(1):1-12.

Kontsedalov, S., Y. Gottlieb, I. Ishaaya, R. Nauen, R. Horowitz, and M. Ghanim. 2009. Toxicity of spiromesifen to the developmental stages of Bemisia tabaci biotype B. Pest Manag. Sci. 65(1):5-13, https://doi.org/10.1002/ps.1636.

Krauter, P.C., K.M. Heinz, and S. Arthurs. 2017. Protecting unrooted cuttings from sweetpotato whitefly, Bemisia tabaci (Hemiptera: Aleyrodidae), during propagation. J. Insect Sci. 17(4):82, https://doi.org/10.1093/jisesa/iex056.

Martin, J.H. and L.A. Mound. 2007. An annotated check list of the world's whiteflies (Insecta: Hemiptera: Aleyrodidae). Zootaxa 1492(1):1-82, https://doi.org/ 10.11646/zootaxa.1492.1.1.

McGrath, M.T. 2004. What are fungicides? Plant Health Instr. 0825:1, https://doi. org/10.1094/PHI-I-2004-0825-01.

Perring, T.M., P.A. Stansly, T.X. Liu, H.A. Smith, and S.A. Andreason. 2018. Whiteflies: Biology, ecology, and management, p. 73-110. In: W. Wakil, T.M. Perring, and G.E. Brust (eds.). Sustainable management of arthropod pests of tomato. Academic Press, London, UK, https://doi.org/ 10.1016/B978-0-12-802441-6.00004-8.

Rihn, A. and H. Khachatryan. 2016. Does consumer awareness of neonicotinoid insecticides influence their preferences for plants? HortScience 51(4):388-393, https://doi.org/10.21273/HORTSCI.51. 4.388 .

Stevens, T.J., R.L. Kilmer, and S.J. Glenn. 2000. An economic comparison of biological and conventional control strategies for whiteflies (Homoptera: Aleyrodidae) in greenhouse poinsettias. J. Econ. Entomol. 93(3):623-629, https://doi.org/ 10.1603/0022-0493-93.3.623.

U.S. Department of Agriculture, National Agricultural Statistics Service. 2019. Census of horticultural specialities. Potted flowering plants sold for indoor or patio uses 
sold: Table 9. 11 May 2021. <https:// www.nass.usda.gov/Publications/Ag Census/2017/Online_Resources / Census_of_Horticulture_Specialties/hortic_ 1_0009_0010.pdf>.

Vafaie, E.K., H.B. Pemberton, M. Gu, D. Kerns, M.D. Eubanks, and K.M. Heinz. 2020. Whitefly abundance on rooted poinsettia cuttings and finished poinsettias. HortTechnology 30(4):486-491, https:// doi.org/10.21273/HORTTECH0453219.

Vafaie, E.K., H.B. Pemberton, M. Gu, D. Kerns, M.D. Eubanks, and K.M. Heinz.

2021. Using multiple natural enemies to management sweetpotato whiteflies (Hemiptera: Aleyrodidae) in commercial poinsettia (Malpighiales: Euphorbiaceae) production. J. Integr. Pest Manag. 12(1): 18, https://doi.org/10.1093/jipm/pm ab010.

Van Driesche, R.G., S.M. Lyon, M.S. Hoddle, S. Roy, and J.P. Sanderson. 1999. Assessment of cost and performance of Eretmocerus eremicus (Hymenoptera: Aphelinidae) for whitefly (Homoptera: Aleyrodidae) control in commercial poinsettia crops. Fla. Entomol. 82(4):570-594.

Wang, X.-W., P. Li, and S.-S. Liu. 2017. Whitefly interactions with plants. Curr.
Opin. Insect Sci. 19:70-75, https://doi. org/10.1016/j.cois.2017.02.001.

Wei, X., H. Khachatryan, and A. Rihn. 2020. Consumer preferences for labels disclosing the use of neonicotinoid pesticides: Evidence from experimental auctions. J. Agr. Resour. Econ. 45(3):496-517, https://doi.org/ 10.22004/ag.econ.302462.

Wollaeger, H.M., K.L. Getter, and B.K. Behe. 2015. Consumer preferences for traditional, neonicotinoid-free, bee-friendly, or biological control pest management practices on floriculture crops. HortScience 50(5):721-732, https://doi.org/10.21273/ HORTSCI.50.5.721. 